\title{
Mapping a Religious Landscape
}

Since he was the patron deity of ascetics, hermits, and other 'outsiders,' worship of the Hindu God Siva often evokes a vision of antinomian practices: naked mendicants with matted hair, who spend their days stalking cremation grounds, human skulls in hand. While such activities were the purview of certain specialists, early medieval literary and material sources, in fact, present a socially supported, even domesticated, body of religious practitioners whose concerns for prosperity and well-being were expressed through the veneration of images, monuments, and places associated with Siva, and other deities affiliated with him. Far from rejecting the established norms and hierarchies of the social worlds in which they operated, these sources reflect a desire to make a Śiva-centered religion compelling to the uninitiated or lay practitioner. Attention to these modes of Śaiva devotion permits a more pixilated vision of community that is attuned to the social complexity and diversity of premodern religion in practice.

Rather than occupying a realm of norms, prescriptions, or beliefs, the worship of Siva in the lived world of Early Medieval India (c. 6th-1oth centuries $\mathrm{CE}$ ) constituted a repertoire of spatial and material practices. The central concern of this study is to recover these practices and better understand how religion operates through landscapes by exploring the sites, memorials, and monuments where early Siva religion was practiced and by discerning possible connections between these places. For worshippers of Śiva, community was inherently localized and belonging was something recorded tangibly in space. Interventions in the built landscape varied greatly in scale-ranging from a single memorial shrine to a monumental temple-but the social functions of these spaces display clear parallels. In the surviving literary, epigraphic, and material sources, sanctified spaces emerge clearly as loci of interaction capable of catalyzing remarkable social synergies between members of disparate groups: from kings and priests to horse traders and potters. By exploring the ties between the practices of Śiva devotees and the locales in which they were embedded, this study reflects critically upon the ways in which community building is coincident with place-making.

The places that occupy the heart of this study were sanctified spaces embedded within political and economic networks in which they served multiple purposes. Evidence of these uses is preserved in the material and textual records, the enduring and tangible marks that people and communities make on 
the spaces they inhabit. Religious institutions mediated the tension between itinerancy and stasis, cultivated a sense of being grounded and at home in the world, and demonstrate how people imagined themselves as 'Śaiva' in Early Medieval India. Coming to terms with this inherent multivocality, the ability to accommodate multiple needs and concerns, not to mention devotional repertoires, is essential to recovering the spatial practices associated with the development of early Śaiva religiosity.

\section{$1 \quad$ Purāṇic Topography}

The early Skandapurāna (550-650 CE) has provided a critical impetus for this project of rethinking early Śaiva history. This new source affords an unprecedented glimpse into the growth of the earliest community of Śiva devotees called the 'Pāśupatas', (a name that is derived from one of Śiva's many epithets, Paśupati, 'Lord of Creatures'). Once believed lost, the text had been known only obliquely from testimonia in digests of brahmanical customs and social regulations whose authors cited passages of this enigmatic source to support their prescriptions. ${ }^{1}$ The earliest stratum of the text is preserved in Nepalese palmleaf manuscripts, the oldest of which is dated $810 \mathrm{CE}$. The ongoing critical edition, based on these manuscripts, is to be distinguished from a text of the same name printed by the Venkateśvara Press in 1910, which records an entirely different textual tradition recovered from fragmentary 18 th century manuscripts, which were identified in their colophons as pieces (khandas) of this earlier, authoritative Skandapurāna. Likely Pāśupatas themselves, the text's authors did advocate asceticism, together with the cultivation of somatic and mental techniques (yoga) that provided a means for certain accomplished practitioners to attain such a level of skill in their practice that they achieve union with the Lord upon death. At the same time, they acknowledge the values of the laukikas - the 'people in and of the world' (loka) — and praise the salvific potential of pilgrimage to Śiva's many shrines (i.e. his 'abodes,' āyatanas) and worship of his iconic emblem (linga), definitive features of the devotional repertoire of early medieval Śiva worshippers (māheśvaras), as they still are today.

Early Śaiva religiosity was inherently emplaced - that is, organized around spiritually charged natural places and the shrines that proliferated around them. Praise of these sanctified spaces, and enumeration of the merits that

1 On these passages in the Dharmanibandha literature see SP I, 14-16. 
accrue to a person who visits them are defining themes of the Skandapurāna. ${ }^{2}$ In their mapping of the Śaiva religious landscape, the authors designate a small region of northwest India as the "primordial Pāśupata landscape" (paśupateh kșetram purānam), ${ }^{3}$ an area venerated as the birthplace of the Pāśupata movement. ${ }^{4}$ The geography of community begins in Kārohana, a locale in southern Gujarat where Śiva reportedly descended to earth in each cosmic age. The sanctity of this region radiates to other important sites in northwest India through the Lord's agents, who were active in disseminating the Pāśupata doctrine far beyond the center of Kārohana. In this way, the Pāśupata landscape extended beyond the narrow boundaries of Kārohana to claim a larger territory that included locales within the modern Indian states of Maharashtra, Gujarat, Madhya Pradesh, and Rajasthan.

\section{$2 \quad$ Political Territory}

Due to its geographic centeredness, the Pāśupata landscape was at the center of the political dynamism and religious efflorescence that defined Early Medieval India between the 6 th and the 1oth centuries $\mathrm{CE}$. It was the meeting point for the various socioeconomic networks that crisscrossed the subcontinent via the primary routes of trade and travel. It was also a highly coveted political space where many ambitious elites vied for control of territory and resources. Until relatively recently, the early medieval was a historiographical 'Dark Age', thoroughly obscured by the Gupta Empire's so-called 'Golden Age' (4th-6th century CE). Contributions of scholars such as B.D. Chattopadhyaya, James Heitzman, Herman Kulke, and Cynthia Talbot reoriented the historiography to show that this was a time of significant social change marked by increasingly localized political and economic networks, the flourishing of regional devotional movements, and innovations in temple and imagecentered religious practices. At the center of these nascent polities and emerging settlements were localized groups of traders, artisans, and mercantile guilds. Epigraphic sources attest to the autonomy of these groups, which

2 Each of the published volumes address this theme in varying degrees. On the pan-Indian networks of holy places connected with the movement see Peter C. Bisschop, Early Śaivism and the Skandapurāna: Sects and Centers (Groningen: Egbert Forsten, 2006); on Vārānasaī see SP IIA; on the Vindhya region of Central India see SP III.

$3 \mathrm{SP}_{\mathrm{S}}$ 167.136. See text, translation, and discussion of this section of the Skandapurāna in Chapter 1.

4 Although kșetra means "field, area, or realm" I adopt 'landscape' as a translation since this field contains various important collocations of Śaiva places and monuments. 
often operated independently of ruling elites. Called by various names (commonly 'nagara') corporate bodies and collectives exerted a considerable socioeconomic and juridical influence by establishing laws as well as by using their influence to levy taxes and tithes on goods with which to support temples and religious institutions.

Discussions of political power in early India have too often emphasized exclusionary strategies; that is, authority has been viewed as concentrated in networks of personal dominance. This is evident in the historiography's preoccupation with royal personality and genealogy, as in the persistent description of cultural activities as a means of 'legitimizing' a ruler's exclusive claims to sovereignty. One effect of this preference for exclusionary strategies is a legacy of inexact terminology to describe political formations-e.g. feudatory, vassal king, minor dynasty, etc. While these terms are common scholarly parlance, they are imprecise insofar as they suggest a stable political hierarchy rather than reflecting the reality of a highly contested political space in which multiple levels of authority were operating. If we read beyond the genealogical sections of inscriptions - and the hyperbole used to glorify particular rulerswe can see political relationships shaped equally, if not largely, by corporate tactics. This corporate concept does not deny hierarchy or imply that a society was egalitarian; rather, it encourages us to see power as enacted, claimed, materialized, and contested through multiple collective bodies and individuals engaged in evolving affiliations.

This same notion of dynamism and interaction forms one of the overarching themes of the Pāśupata origin story recorded in the Skandapurāna. As the next chapter will discuss, this story provides an account of the geographic expansion of a particular religious formation via a network of cultural agents and connected places. While the Skandapurānás presentation of a Pāśupata network is highly rhetorical, evidence from inscriptions serves to both complement and complicate the text's vision by introducing other agents, associations, and locales operating within the boundaries of the Páśupata landscape the text's authors have drawn. These sources attest to the burgeoning of social and geographic mobility in the early medieval period: mercantile groups actively conducted trade, agriculture expanded, and areas that had previously been uncultivated or sparsely inhabited were settled. Of course, these networks did not operate in a vacuum. It is revealing that much, indeed, almost all, of what we know of the textures and rhythms of social interactions at this 
time comes from epigraphic sources recording acts of pious giving to temples and religious institutions. Many of these were given to places we could properly characterize as Śaiva - meaning that an instantiation of Siva, usually in the form of a linga, was the principal deity honored in the temple. For these reasons, the Pāśupata landscape provides a valuable opportunity to recover some of the complex interactions between the diverse groups that populated the region. And this complexity is significant since it demonstrates that networks do not always conform to an established pattern, that people cross boundaries, and that interactions may be unexpected.

Despite recent advances prompted by the presentation of newly edited texts, a social history of early Śaivism has not yet been written. The image of the Pâśupatas that has dominated the field is informed primarily by philosophical treatises and esoteric ritual manuals and, not surprisingly, that image is one of an exclusively male community of ascetics and literati removed from the larger sociocultural milieu of Early Medieval India. Some recent studies have attempted to situate the Pāśupata movement within its broader social contexts in an effort to explain a perceived dominance of Śaivism in the early medieval religious landscape. The groundbreaking work of Alexis Sanderson has loomed especially large in this regard. Sanderson's seminal 2009 study characterized Early Medieval India as the 'Śaiva Age' and, in it, he outlined a historical scenario that is now largely assumed in the field of early Śaiva studies. ${ }^{5}$ This article attributes the popularity of Śaivism to the ingenuity of religious specialists who succeeded in adapting their religious practices and ideologies so as to be compelling to regional rulers. The adoption of Śaiva brahmin teachers in the position of royal preceptor (räjaguru) by regional rulers marked a significant integration of these religious specialists within spheres of political power. In return for their positions of prestige in the royal court, the rājagurus granted kings initiation (śivamandaladīkșā). ${ }^{6}$ The position of these initiated rulers was unique since they were exempted from the usual rigors of Śaiva practice. The textual sources Sanderson has consulted emphasize instead the king's role as "head of [the brahmanical social order of] the caste-classes and religious disciplines (varnāśramaguruh).."7 In Sanderson's words, "The king was considered to qualify for this less arduous route to liberation by reason of his royal obligations. He was therefore required to adhere only to the obligations of an

5 For example, see the "Introduction" to the 2013 Special Issue of the Indo-Iranian Journal by Nina Mirnig and Natasja Bosma. Indo-Iranian Journal 56 (2013): 201-204.

6 Alexis Sanderson, "The Śaiva Age: The Rise and Dominance of Śaivism during the Early Medieval Period" in Genesis and Development of Tantrism (Tōkyō: Sankibō Busshorin, Heisei 21, 2009), 41-350.

7 Sanderson, "The Śaiva Age", 255. On the textual references see n. 591 and n. 593. 
uninitiated devotee of Śiva taught in the texts of the Śivadharma corpus, which in his case were principally to support the religion and its institutions and to sponsor and appear in conspicuous ceremonies in the civic domain." ${ }^{8}$

The bonds between religious specialists and spheres of political power should not be discounted; indeed, Śaivism became a popular idiom in epigraphic and visual media for expressions of political power and royal persona in India and beyond. But this is only a small part of the story. Privileging a 'top down' vision of Śaiva history has resulted in current scholarship paying too little attention to the participation of non-elite or non-royal actors-artisans, traders, rural agriculturalists, and women. I have worked to recover some of these marginalized voices through (re)readings of early medieval epigraphic sources from the region-stone inscriptions, copperplate grants, donative records, etc. Since these records detail specific events and cultural practices, they preserve valuable evidence of religion in practice that is often absent from traditional literary sources. The inscriptions that I reference in the following chapters have all been edited and published and most of them have been translated. Despite being part of the established 'Indological record' much of the rich detail these records preserve about religion as lived and practiced has gone largely unnoticed. Historians have tended to read inscriptions selectively for details of dynastic genealogy and military history and, as a consequence, the majority of early medieval epigraphs have yet to be mined for a wealth of other kinds of information.

In the paragraphs above I have referred to the agents I am concerned to study as 'marginalized' voices. This silence is the result of a prevailing focus on dynastic history in the contemporary historiography. Since this project has approached the historical sources with different questions, the contributions of individuals and groups from other social strata have emerged with a greater force and I have chosen to emphasize them. I should also clarify that describing these voices as those of 'non-elite' or 'non-royal' agents, is not meant to suggest that I am writing a history of the 'subaltern' in premodern India. The opposite may be true. The fact that these voices are present in the historical record is significant in itself and suggestive of their social ascendance and ambition. While the endowment of temples is typically attributed to ruling elites, these monuments were much more than self-aggrandizing statements of royal power and prestige. The work of endowing and managing temples catalyzed synergies between individuals and communities from a wide variety of social strata. Artisans, traders, guilds, etc. were far more active as patrons and donors than their royal counterparts. Since Indian temples were large, highly

8 Sanderson, “The Śaiva Age”, 254. 
elaborate works of art carved in stone, these investments would have required access to a substantial economic surplus and the ability to mobilize resources over time to ensure the structural and ritual maintenance of the monument. In addition to requiring the expenditure of capital, these religious centers were also storehouses of wealth, both material and symbolic. They controlled significant immovable assets (for example, market stalls and agrarian lands) and participated in the monetized economy through rents paid in cash, and taxes paid to the institution by guilds and traders. As the products of collaborative endeavors that were designed to commemorate relationships and nurture social sodalities, the space of the temple occupied the center of a settlement or polity and marked the heart of the socialized early medieval world.

I use the term 'landscape' to designate a "lived space,"9 a term that encompasses the physical features of a natural landscape, the social and cultural spaces therein, and the values that the inhabitants attach to both. This study foregrounds the multivocality of the Pâsupata landscape, which was given shape and meaning vis-à-vis the myriad activities of individuals and communities. ${ }^{10}$ But this region was not something acted upon as a passive backdrop upon which history unfolded, it was instrumental in the construction of religious and political identities and in shaping the realities of those people who lived it.

In addition to the study of narrative and epigraphic sources, on-site research has been integral to my study of this landscape as a lived space. The Śaiva temples and monuments of Early Medieval Northwest India preserve a rich material archive recording histories of the lived religious world that cannot be accessed through textual sources. Using the material record it is possible to approximate some sense of what Barbara Bender has termed the "subjectivity", of a landscape, which is to say, a material recording of human interactions in

9 Henri Lefebvre employs "lived space" as part of a conceptual triad that also includes "conceived" and "perceived" space. Lived space is the locus of culture and of social activity. Henri Lefebvre, The Production of Space, trans. Donald Nicholson-Smith (Cambridge, MA: Wiley-Blackwell, 1991); W.J.T. Mitchell, "Preface: Place, Space and Landscape" in Landscape and Power, ed. W.J.T. Mitchell, 2nd edition (Chicago: University of Chicago Press, 2004) vii-xii.

10 In Margaret Rodman's words, "places, like voices, are local and multiple. For each inhabitant, a place has a unique reality, one in which meaning is shared with other people and places. The links in the chains of these experienced places are forged in culture and history." Rodman, "Empowering Place: Multilocality and Multivocality," American Anthropologist 94 (1992): 640-656. 
a particular time and place. ${ }^{11}$ As with the Skandapurāna narrative, I approach these other historical sources as recording an ongoing conversation in which different cultural agents—religious specialists, political elites, laywomen, artisans, merchants, and others-offer their accounts of this Śaiva landscape. In addition to human agents and collectives, this study also considers the use of material culture-monuments, memorials, images, etc.—as religious media through which notions of belonging and identity were expressed. As participants in the social worlds of the early Śaiva landscape they, too, are imbued with a kind of agency. Accessing these accounts is not done merely to create a single integrative map that corroborates what the Skandapurāna reports. Rather, these accounts reflect various vernacular geographies operating within a larger religious landscape.

\section{$5 \quad$ A Map of the Present Work}

This project spans a broad geographic area and attempts to synthesize multiple bodies of historical sources; as a consequence, it was necessary to limit and circumscribe the inquiry through a selective chronology, regional frame, and selective sub-regional focus. The text of the Skandapuranna provides one set of temporal parameters. The editors have dated the text to the late 6th-early 7 th centuries. The 6th century thus marks the beginning of my formal inquiry. Since a primary aim was to map the growth of religious communities in both place and time, I extended my temporal frame to include sites and evidence from a period up until the early 1oth century. Widening my chronological focus allowed me to engage more of the surviving evidence and use it to present a more complex historical picture in which the interactions of economic, political, and religious networks at a micro-regional level produced distinctive religious landscapes.

The Skandapurāna has also inspired the geographic scope of the projectthe mapping of the Pâsupata landscape in the text provided the starting point and initial parameters for my own mapping. Although, as the authors were selective in identifying particular points in their map, I was also selective in choosing the sites to include in this study. In determining the project's spatial parameters, I worked with two basic criteria: 1) that the site falls within the boundaries of the text's Pāśupata landscape and 2) that there was sufficient material and, or, epigraphic evidence to shed some light on non-royal

11 Barbara Bender, “Time and Landscape," Current Anthropology 43 (2002): 103-112. 
community formation. Point two is rather straightforward, but the first qualification requires some explanation. The Skandapurāna provides only a selective overview of key locales within the religious landscape. The areas I survey, however, are places that occupied the interstices of this narrative map. Given that this textual cartography is a rhetorical and imaginative construction, I did not feel it necessary to consider only the places explicitly marked in it. My effort to recover the region as it was 'lived' required a survey with a broader scope. Many of the places I explore are those that the map merely takes for granted, since they fall within the broad parameters of the narrative geography.

Chapter 1 introduces the narrative of Pāsupata origins preserved in the most archaic layer of the Skandapurāna. The text's authors designate a small region of northwest India as the 'primordial Pāśupata landscape,' the place where Lord Siva purportedly descended to earth and initiated the dissemination of the Passupata doctrine. The authors specify that Siva assumed a human form as the teacher Lāguḍi (viz. Lakulīśa) at Kārohaṇa in southwest Gujarat. In the course of his terrestrial wandering, the teacher initiates four students, each of whom presided over a prestigious locale in northwest India - the cities of Ujjain, Mathurā, Jambumārga, and Kanauj. In my analysis of this 'imagined geography' I examine the text's rhetorical aims to present a cosmological vision of a Śaiva world, provide a normative model for community, and stake a geopolitical claim.

Using the early Skandapurāna as the terminus post quem for the narrative construction of the Pāsupata landscape, Chapters 2, 3, and 4 look beyond the textual horizon. In these chapters other historical sources-inscriptions, monuments, and images-become the focal points for the construction of new narratives within this geographically circumscribed area. Each of these chapters introduces a distinct sub-region within the Pâsupata landscape: northern Mālava or Uparamāla in central India, an area of northeast Rajasthan traditionally called Sapādalakșa, and the North Konkan coast. In order to organize diverse bodies of evidence, each chapter adheres to a similar structure. I begin by introducing the region's physical terrain and outlining the important historical events, political patterns, and economic realities that contributed to its distinctiveness. Next, I situate early Śaivism within the regional social geography, by looking specifically at inscriptions for evidence of patronage of Śaiva institutions. When it is possible, I try to represent the range of donors and their motivations for donative practices in order to get a sense of the social embeddedness of the tradition. The third section presents and analyzes the material evidence with a special attention to patterns in iconography. My attempt to access the lived history of places as preserved in the material record 
has involved extensive fieldwork and multiple visits to particular places. I am certain that additional study and future site visits will serve to further nuance this presentation.

Chapter 2 traces the development of Śaiva religious centers in the heartland of Uparamāla. Here I focus special attention on mapping and comparing expressions of Śaiva identity amongst socially ascendant groups in the political centers of Daśapura and Chittorgarh with those of mercantile communities settled in Kansuāñ, Jhālrāpāțan, and Indragarh in the hills to the north. Evidence coming from both these areas highlights the flexibility of Śaivism, which was employed as a political idiom and expression of might for urban elites and invoked as a source of protection and alleviation of suffering by mercantile groups.

Chapter 3 moves northeast to Sapādalakșa. I stress the importance of the region's unique geography, which was defined by a series of large saline lakes. Trade in salt from these lakes supported the creation of the monumental royal temple complex on Mount Harșa and the Pāśupata religious specialists in residence there. I compare the expressions of Śaiva identity at Harșa with those in the frontier town of Kāman where different socioeconomic formations and political patterns contributed to a distinctly irenic expression of Śaivism that diverges in significant ways from the idiom at Harșa.

Chapter 4 concludes the survey of the Skandapurāna's mapping of a Śaiva landscape in the North Konkan coast and the Deccan hinterlands, the southernmost boundary of the Păśupata landscape. I begin by presenting evidence to counter the dominant scholarly narrative that presents the monumental Śaiva sites as produced by the patronage of the Kalacuri rulers. I propose an alternative history by showing that unique patterns in coastal geography and regional trade in this port polity created a corporate donative culture that shaped the Śaiva religious landscape of the North Konkan, in much the same way as it had supported an earlier network of Buddhist sites.

Chapter 5 concerns the iconography of Lakuliśa, the tradition's founding teacher, and reads his appearance in images as a reflection of or response to particular concerns of the developing Śaiva religious community. This chapter revisits some significant representations of Lakuliśa images from the sites surveyed in the previous chapters, and reflects upon what these differences might reveal about the religious landscape in which they were conceived. I pay particular attention to the formal elements of the icons and their place in temple spaces in order to identify the multiple ways in which these icons could have been 'read' and interpreted. I conclude that Lakulissa was not only a potent sign of Pāśupata identity; his various attributes signifying power, fertility, and protection reflect a multivalent persona that would have resonated with a broader religious community. 